Archaeological Journal

\title{
Ritualistic Ecclesiology of North-East Somerset
}

\section{J. Lewis André F.S.A.}

To cite this article: J. Lewis André F.S.A. (1899) Ritualistic Ecclesiology of North-East Somerset, Archaeological Journal, 56:1, 144-158, DOI: 10.1080/00665983.1899.10852815

To link to this article: http://dx.doi.org/10.1080/00665983.1899.10852815

曲冓 Published online: 16 Jul 2014.

Submit your article to this journal $\widetilde{ }$

III Article views: 2

Q View related articles $₫$ 


\section{RITUALISTIC ECCLESIOLOGY OF NORTH-EAST SOMERSET.}

By J. LEWIS ANDRE, F.S.A.

Just ten years ago, I had the honour and the pleasure of reading a paper before this 'Institute, which I ventured to entitle Ritualistic Ecclesiology of North-east Norfolk, and I now beg to offer some remarks of a similar character on the churches of a corresponding portion of the county of Somerset.

As in the structures of our churches we find marked localisms in their details, and also rich and noble edifices in one district, and comparatively poor and simple ones in another, so in some districts the ritual arrangements are strikingly prominent, whilst in others they are far less pronounced. It is also to be noticed that whilst in one locality we find certain ritual requirements to have been objects of much care, in others they have been often neglected. In Norfolk, for instance, it is evident that much attention was bestowed on the font, and it is made as conspicuous and as elaborate as possible, whilst in Somerset the baptismal vessel seems to have been considered of much less importance. On the other hand, the western county has made the sancte bell cote, and the rood stairs turret almost indispensable adjuncts to each church, whilst in Norfolk the sancte bell cote is very rarely met with, and the rood stairs turret is a much less prominent feature.

The original altar stones remain in three north-east Somerset churches : of these two slabs are at Weston-inGordano where they have been replaced, one in the chancel, and the other in the chapel of S. Mary Magdalen. At Long Ashton the altar stone lies under the present altar, whilst at Portbury the slab lies in the cross passage of the north aisle, and bears upon it a sixteenth century epitaph. It was originally eight feet long by three wide. but about a third has been lost. 
A long moulded panel over the altar site in the south chapel at Chelvey, is undoubtedly a portion of the original reredos, and the east window over it is flanked by niches of large size. Part of the reredos of the high altar remains at Congresbury, consisting of large niches with smaller ones over them, and at Nailsea the lowered sill of the east window indicates where the altar tables used to be. Clapton-in-Gordano has a remarkable reredos with two large brackets on either side of the altar, of 1st P. foliage work, and these still support altar candlesticks of brass, which are no doubt the successors of the original altar lights, placed not on the altar, it will be remarked, but on each side of it. These candlesticks are of the wreathed kind with very broad bases, suited exactly to the size of the stone brackets; they are about sixteen inches high, and have movable nozzles, being probably of seventeenth century date like the silver ones at Lambeth Palace Chapel.

At Uphill the high altar had no window over it, and there does not appear to have been an east window in the north chapel in the neighbouring church at Worle.

Chapels in East Somerset are often east of the south porches, as at Kew Stoke, East Brent, and Chelvey, and the latter example appears to have been designed expressly to include a range of three tombs in the south wall. The three tombs form one continuous design and each is under a two-light window. At Nailsea the north chapel is only six feet wide and is covered by a lean-to roof. A remarkable transeptal chapel on the north side of the chancel at Portbury will be noticed further on.

At Compton Bishop is an extremely interesting and beautiful 1st $P$. piscina. It is of the double form and has two arches within an enclosing one; in the head of the latter is an aumbry which retained its original door and strap hinges till recently, when they were replaced by fresh ones. At Congresbury is a single bowl piscina under two arches, the drain being beneath the western one. A peculiar but elegant 3rd P. piscina with foliaged and bracketed bowl is at Berrow, and in the porch of the same church is a stoup exactly like it. Piscinas occur in the east walls at South Brent and Yatton, the latter forming an elaborate 3rd P. composition, and at Worle 
there is a drain formed in the flat sill of a window in the east jamb of which there is an aumbry of small size.

Sedilia are not common, but at Portbury there are two sets, one in the chancel the other in the south aisle, or azel as it is termed in Somerset. The former is of very rich 1st P. work, with trefoil arches, and with the piscina forms one design. The aisle sedilia are very similar but plainer, and the piscina has been fitted with a stone shelf, though the rebate for the wooden one remains. At Worle there are two seats under ogee headed and crocketted arches. Ranges of triple sedilia of modern work are at Kingston Seymour and Wraxall.

There are numerous examples of squints, Clevedon church possesses two, one from each transept, and there are single ones at Axbridge, Banwell, Nailsea, Wraxall, Worle, and Yatton. At Clapton-in-Gordano one in the north chapel has a bracket piscina connected with the flat sill. Most of these squints are plain in character; but at Kingston Seymour, the one from the south aisle into the chancel breaks into the jamb of a window of which part of the mouldings are cut away, whilst the rest form a mullion dividing the hagioscope. In the north-east angle of the tower at Lozton there is a noteworthy example, as the tower forms a south porch and it is evident that the squint was to enable a person standing in the tower to ring a bell at the Sanctus and Elevation in the Mass, celebrated at the high altar; this squint is also interesting from its retaining its original grille.

As already noticed the sancte bell cote forms an important feature in most of the east Somerset churches, and many retain the sancte bell within them, as at Clapton-in-Gordano, Portishead, Weston-in-Gordano, Wraxall, and Wrington. At lickenham this feature is very small, and at Futton it is a poor modern Gothic affair. ${ }^{1}$

A writer in the Gentleman's Magazine of 1794 remarks of a sancte bell hanging in its cote at Mells, Somerset: that it was then "usually rung as soon as the officiating

1 Pt. II, p. 702. Reprinted in Gent. Mag. Liórary, Topography, pt. X, p. 281. The sancte bell still hangs in its cote at Wooton S. Mary, Beds, and at Jong Compton, Halford, and Wickford, Warwickshire; whilst at Great Stough- ton, Hants, the bell, cote, and the chain by which the former was rung, still exist at Gadshill, I. of Wight; the bell is in a recess at the apex of the gable of the $\mathrm{S}$. transept. 
minister was in his place to give notice to the people without, that the service is about to begin." This usage may, I think, be an ancient one, as it was customary in the Pre-Reformation ritual for a small bell to be rung as the priest left the vestry to begin mass.

I have only met with one Easter Sepulchre: it is at Hutton, and has at the back of the recess a brass for Thomas Payne, Esquire, dated 1528. The canopy is panelled, but the front of the tomb is a perfectly plain piece of walling. At Clevedon a perfectly unadorned arched recess may have served for an Easter Sepulchre, and the chapel before alluded to at Portbury may, it has been conjectured, have been applied to the same purpose. This chapel is extremely curious, being of a transeptal form, gabling north and south, and standing just outside the sanctuary of the chancel; a passage, or aisle, connecting the chapel with the north aisle of the nave, and passing behind the north stalls. The whole is of stone, the roof being a pointed barrel vault with ribs following the outline of the vaulting. Whatever was the use of this singular chapel, it is clear that it was intended to be approached from the nave aisle and not from the chancel. There are no traces of an altar or its piscina, which favours the theory that this transeptal addition to the choir may have been employed as a suitable place for the erection of the Easter Sepulchre, and may not the fact of the whole structure being in stone suggest a grave hewn in a rock, if the use of it for a representation of Our Lord's tomb be the right solution of its purpose ?'

Low-side windows are not at all common, and the only instance $I$ can cite is at Bleadon, where a two-light 2nd P. window has a transom across both openings and under it very oddly cut tracery with quatrefoils over irefoiled lights, the hooks for the hinges of the shutters remaining within memory. This lychnoscope, be it observed, is on the south side of the chancel, whilst the village of Bleadon is north of the church.

1 It would be interesting to ascertain if in England the Easter Sepulchre was ever erected in any other position than near the north side of the high altar. On the continent, in Germany at least, its locality was not so restricted, for $\mathrm{Dr}$. Lubke says that the sepulchre at Con- stanz Cath., was "in a chapel behind the choir," at Ground, Holy Cross, "in the centre chapel of the choir corridor," and at S. Mary's, Reutlingen, "at the end of the northern side aisles." See Lubke, Ecclesiastical Art in Germany. pp. $250,251$. 
Very curious stalls exist at Weston-in-Gordano, and date as far back as the fourteenth century. Till recently these choir fittings were perfect, but now only those on the north and south sides remain. They differ in several respects from the commoner fifteenth century examples, as each curved elbow has an upright piece in front of it, and the subsellia have rude carvings of a man holding a bolt or short arrow in each hand, and other devices.

At Worle are five miserere stalls on each side of the chancel, and these according to tradition came from the neighbouring Priory of Woodspring. They are good examples of 3rd P. work, and on one is carved a capital $\mathrm{P}$ and the letters $\mathrm{R}$ and $\mathrm{S}$ conjoined.

Although in north-east Somerset there are no examples of fonts which can compare in splendour with many in East Anglia, there are several noteworthy ones, and it is remarkable that a large number of Norman fonts are retained in churches possessing no other features in that style. Out of thirty churches I visited, thirteen have twelfth century fonts, or nearly half, two are of thirteenth century date, seves of fifteenth century, and the rest are modern. Six of the Norman examples hare circular bowls and six are square, and as regards the last named they are smaller than usual, and the basins are also foursided, and not circular as is generally the case, like those at East Meon, Hants, and Willesden, Middlesex, tro examples of many such. At Chelvey there is an octagonal Norman font bowl, which appears to have been originally a square one, altered to its present form in the fifteenth century, a transformation wrought on some other fonts at that period as, for example, at Ingoldesthorpe, Norfolk, and on another now forming part of an ecclesiological rockery in the churchyard at All Saints', Warham, in the same county. At Banwell the font is a circular one covered with 3rd P. ornamentation, including a cornice of quatrefoiled panels, above peculiar upright branches of foliage, but as the round bowl is but seldom, if ever, met with in late Gothic work. it is probable that this tont is a Norman one of originally plain character decorated in the fifteenth century. If so, this example is not singular, for there is a very striking one at Mountfield, in Sussex, where, as in some cases in that county, the 
font bowl of Norman work was a very large but perfectly plain circular mass, but late in the fifteenth century the upper edge of the bowl has been worked into a battlement cornice, and panels with fleur-de-lis and other foliage cut out in the surface of the bowl.

By far the most curious of the Norman fonts in northeast Somerset is the one at Locking. It is square, and at each angle is alternately a full length figure of a man or woman with their arms bent back in an impossible manner, and clasping each other's hands, the rest of the bowl is filled in with two rows of entwined spotted snakes. I regret to say that at Yatton the plain but good circular Norman font has been destroyed, and buried I believe in the church, whilst at Portishead the simple but excellent little font of the same period has been discarded for a florid Gothic memorial one, and now stands in a corner of an aisle.

A pretty 1st . P. font with trefoil arches on the bowl is at Tickenham, and at Kenn there is an octagonal bowl supported by a cluster of 1st P. pillars.

A very beautiful but mutilated $2 \mathrm{jid} P$. font has been transferred from the old church at Uphill to the modern one. It has remarkably crisp foliage work of German character on an octagonal bowl. Another interesting font in the same style is at South Brent, in which the bowl is a waved or ogee quatrefoil in outline, which shape is followed in the basin.

At Clapton-in-Gordano the font bowl is also a quatrefoil, and now has the remarkable peculiarity of a basin sunk only about two inches, resembling in this respect some shallow piscinas.

The 3rd P. fonts are not noteworthy, but one at Wrington has half effigies of angels singularly naturalistic in their treatment, a feature characteristic of the sculpture in this locality when of late fifteenth century date. No other religious emblems are to be noticed on the northeast Somerset fonts, except that at Nailsea there is an example bearing a shield with the five wounds.

Only five out of the fonts above noticed retain ancient covers, and these are all of Jacobean date, occurring at Banwell, Compton Bishop, Chelvey, Loxton, and Puxton : they are all octagonal in shape and each has a band of foliage or carving round the base. 
As before observed, the rood-screen, with its loft and staircase turret, formed a very prominent feature in a Somerset church, and in this county occurs the, I believe, unique example of a Post-Reformational rood-loft, which still exists at Rodney Stoke. At Banwell there is a richly painted and gilt screen supporting an equally fine loft carried on fan-shaped groining. Curiously enough, over the doorway in the screen is a shield emblazoned with the arms of France and England, very nearly the position assigned to them on many screens after the Reformation. Traditionally this beautiful work came from Bruton Abbey, but this is disproved by the Churchwarden's Accounts for 1521, where the expenses connected with its erection are fully set forth, and include the expenditure of iiij" "for paper to draw the draft of the rode lofte," and notify the cost of the stained cloth before it. Here the platform before the screen remains, and at Bleadon the stairs to the loft are about six feet west of the chancel arch, indicating that this gallery must have been a wide one in that church. A modern loft has been constructed at Wraxall, but appears to be a narrower one than its predecessor. At Tickenham the loft was over the chancel arch, which is a very low one, and was entered from a doorway in the south part of the wall over it, whilst in the north portion is a lancet for the purpose of looking down into the chancel. Congresbury has a wooden screen above a breast-high stone one, and at Puxton is a very late stone screen of massive character about four feet in height. Loxton retains a late but beautiful screen with the holy doors intact, doors which at Congresbury now adorn a western tower screen. At Portishead fragments of the chancel enclosure were worked up into altar chairs, and at Cheddar into a reading pue. The original painting and gilding of the easternmost bay of the nave roof, over or near, the rood, remains at Cheddar, and the same part of the nave roof is of richer character than the rest at Backwell. The similar decoration at Weston-in-Gordano is modern.

In many churches the rood stairs remain with both doorways, as at Wick St. Lawrence, and most of these stairs were in octagonal turrets of bold projection, and rising above the nave walls occasionally are crowned by 
lofty spirelets, as at Barrington, Winscombe, and Worle. Often they are richly panelled, and when not capped by a spirelet have open parapets. The Barrington example is remarkable in having a very lofty spirelet and bold turret attached to a comparatively insignificant church, and like most of these stairs they are on the north side of the church.

At East Brent, is a large and curiously carved west gallery with highly enriched columns beneath it, erected in the seventeenth century. Berrow has the remains of a quaint gallery set up against the tower walls, and it is somewhat like the last example, and bears the following curious fragmentary inscription on the front-

"I was set up right and even 1637, the yeare of the Lord. Accurst that in the delings are not just. . . ."

I do not know whether the inhabitants of the western counties had any marked predilection for preaching in the middle ages-perhaps they had, for the will of Humphrey, Earl of Devon, dated 3rd September, 1463, directs "that two Franciscan Friars of Exeter should go to every parish church in the counties of Dorset, Somerset, Wilts, Devon, and Cornwall and say a sermon in every church-town or other." Certainly in Somerset we have a large number of Pre-Reformation pulpits, many of them of rich and costly design, highly carved, and several still retaining their original colours and gilding. Like most mediæval pulpits they are small in size and constructed on one plan, being generally attached to the north or south walls of the naves of the churches and entered by stairs contrived in the masonry. In some cases the rood loft stairs serve also as those by which the preaching-place was entered as at Hutton, Nailsea, and Uphill. At Portisheacl the stairs are in a large buttress-like projection with two doorways in the south wall, whilst at Weston-in-Gordano, where the tower stands south of the nave, a passage is hollowed out in the jamb of the arch between the two for the stairs, and the front of the pulpit is flush with the inner face of the south wall, the pulpit itself being a small square chamber quite devoid of ornament. At Compton Bishop the pulpit is also square, but the form which 
the majority of these preaching places take is a half octagon, the sides of which are panelled and the whole carried on an engaged stem or shaft. Among the ornaments on the cornices of these pulpits may be noticed a kind of 3rd P. dog-tooth, and one which occurs on the arch of the porch at the rectory at Congresbury, built about 1470 . This peculiar moulding is a slight indication, amongst others of much greater importance, of the tendency displayed in the latest form of Pointed art to revert to earlier forms, a tendency more fully exhibited at Wrington in the treatment of the inside of the clerestory, where the bays are divided from each other by shafts from which spring large trefoil wall arches, each of which encloses a three-light 3rd P. window. To return from this digression, we find that in Somerset stone pulpits were made until the commencement of the seventeenth century, an example of this period, dated 1621 , is at Dinder, and bears on it the text " Elessed are they who hear the word of God and keep it." A rich wooden pulpit of Jacobean date is at East Brent, and there are plainer ones at South Brent, Tickenham, and Clevedon, the latter with Flemish panels with scripture scenes inserted in it. At Puxton the iron hour-glass frame remains. In several places the mediæval pulpit is said to have come from Woodspring Priorv, which may be true in one case, as at Worle it stands on the site of the south altar in the nave. At Portbury there are two modern pulpits.

At Chelvey, and Clapton-in-Gordano, there are quaintly cut solid bench ends, which somewhat resemble those at Elkstone, Gloucestershire, figured in Parker's Glossary; square bench ends remain at Puxton and Weston-inGordano, and some plain poppy-ended ones are to be seen at Weston, and Clevedon. Both East and South Brent possess beautifully carved seating, and at the latter church the ends have the most complete series of grotesques that I have met with. Good bench ends and seats also remain at Cheddar, and much of the elaborate pewing at Wraxall is made up of old work. At Claptonin-Gordano the western seats are shorter than the rest, and the massive sill to which the bench-ends are fixed is curved to suit the reduced leugth of the pewing, as by this means a free passage round the font is secured, and a 
similar arrangement occurs in some Norfolk churches, as at Barningham-Northwood and Sherringham.

The nave piers at Portbury rest upon nosed plinths nearly five feet square, and evidently intended for seats, whilst a similar bench table runs along the walls of the aisles, a feature which $I$ have heard is to be found in the south aisle at Priddy.

Chests of Jacobean date remain at Loxton and Compton Bishop, the latter standing on four legs, whilst at Portbury is one of those poor man's chests which were directed to be in every church in the sixteenth century; it is about three feet long and strongly clamped with iron, and moreover still serves its original purpose of an alms chest.

A very pretty holy water stoup remains just inside the south doorway at Weston-in-Gordano, the back of the recess containing it being panelled with delicate arcaded tracery. There is also a carved recess for the stoup at Portbury, and, as before noticed, the basin at Berrow is a repetition of the high altar piscina. At Wraxall the bowl has the unusual form of a quatrefoil, and is singularly deep. Priddy is said to have a good stoup.

In 1849 a curious reliquary was found in the north wall of the nave at Kew Stoke, and this has been conjectured to have contained some blood of S. Thomas of Canterbury. A full description, illustrated by engravings, will be found of this reliquary in the sixth volume of the Archoological Journal. A very similar reliquary was discovered many years back in the wall of the north transept at Yaxley, near Peterborough. At Congresbury when putting in a heating apparatus, a very large and massive stone coffin was disinterred, which, for some reason or other, has been supposed to have formed the last resting-place of $\mathrm{S}$. Congar, a hermit who lived there, and has given his name to the parish, but not to the church, which is dedicated to S. Andrew, and in a similar way the village of Kew Stoke is called after S. Kea, though the church is, I believe, one in honour of $\mathrm{S}$. Paul.

One of the most interesting localisms of the ecclesiology of north-east Somerset is connected with several of the south porches. It occurs with slight variations in those of Clapton-in-Gordano, Clevedon, Portbury, Portishead, 
Wick St. Lawrence, Wraxall, and Wrington, and there may be other examples with which I am unacquainted. All of these churches have south porches, and appear to have had galleries across them, the usual arrangement being as follows: In the centre of the inside of the east wall is a doorway connected with stairs which end in the north-east angle of the porch, whilst the space over the inner doorway has a niche, the position of which indicates that the staircase did not lead up to a parvise, but to a gallery or loft. At Weston-in-Gordano this gallery remains perfect, and has a moulded and battlemented girder with curved braces beneath it, the underside of the floor being panelled, and the whole picked out in colours. At Portishead the loft also remains, but in an altered state and now opening into the nave.

As to the purport of these galleries, the general opinion is that they were employed in connection with the Faim Sunday procession outside the church, a theory favoured by a rubric for the ceremonies of that day in the Sarum Missal, which gives the following directions for this procession: "Here let the second station be made on the south of the church where let seven choristers sing in a conspicuous place" the hymn "Gloria laus et honor, \&c." A southern gallery, such as that described here, would thoroughly meet these directions both as to the side of the church and the conspicuous place required, in which the hymn was to be chanted. ' The fact also that a porch was sometimes called "the procession porch," as in the churchwarden's accounts of S. Mary's, Sandwich, favours this theory, which, if correct, shows how exact the observance of this rubric must have been in north-east Somerset, when it was thought necessary to provide a gallery to be used only once in the year, though it seems probable that expositions of relics may have also taken place in these lofts, as they would have been excellently adapted for the purpose.

At Congresbury there is a parvise now made use of as

1 Sometimes the hymn appears to have been chanted from the roof of the church, probably that over the south aisle, as aisle roofs were often lean-to ones and nearly flat. In the caurchwarden's accounts of S. Mary Wool- noth, London, under date 1540 , is the entry, "Item for setting up the rails upon the leds on Palme sunday iijd." See s. Mary Woolnoth, and S. Mary Wooldwich, p. xrii. 
a vestry, and other examples of this chamber are at Winscombe and Yation. Christon possesses a remarkable porch, being entirely of stone, and consisting of a plain barrel vault, on equally plain walls. The church is a twelfth century building, and the late Dr. Neale considered the porch a Norman one, but I confess that to me it appears to be Jacobean, though somewhat similar vaulting occurs in connection with the north porch at Uphill. If in their original places, two brackets in the inside of the east wall of the porch at Kew Stoke, and a niche over a modern door, may perhaps indicate that an altar once stood there.

The only original vestry I know of is on the north side of the chancel at Banwell.

Sculpture appears to have been freely used, and most of the church towers have niches for saintiy figures, as at Banwell, where they contain images of the Blessed Virgin and S. Gabriel; these flank a two-light blank window, in one light of which is a large lily-pot, the whole forming a cleverly introduced Annunciation. At Tickenham the parapet of the tower contains a series of panels carved with events in the histories of SS. Julietta and Ciriacus, the patrons of that church. The Crucifixion was sculptured on a panel inside the east wall of the porch of the old church at Weston-super-Mare; with SS. Mary and John, another example remains on the north wall at S. John's Church, Glastonbury. Neale mentions that the death of the dragon is appropriately set fortn on the rood-screen at Cleeve. The Holy Trinity is met with in niches at East Brent, Wrington, and Yatton, the Blessed Virgin on the tower at East Brent and the porch at Axbridge, and there is a mutilated figure of S. Giles inside Cheddar Church. Sacred persons and emblems occur on the seats at both the Brents.

Although not a ritual feature, I cannot help mentioning that at South Brent the nave floor slopes from east to west at a much greater inclination than any other example I have met with, the fall being probably as much as one in twenty, much greater than the examples in the Sussex churches at Fletching, Portslade, or Rottingdean.

Many sepulchral monuments have sacred sculpture introduced upon them, and at Bleadon there is a very 
elegant panel, now in the porch, showing the Blessed Virgin and Child between kneeling figures of a hooded man and a lady, the whole being enclosed in a crocketled ogee arch of fourteenth century date; whilst at Yatton a very good and nearly perfect Annunciation remains at the back of a fifteenth century tomb in the Newton chapel. At Weston-in-Gordano the monument of Richarde Perseyvale, dated 1483, has, at the back of the canopy, three curious figures of scroll-bearing angels, which are quite naturalistic in treatment, as are the angelic figures on the tomb of Sir E. Gorges, dated 1510, at Wraxall.

I regret to say that at Bleadon there are two fine monumental effigies lying in the churchyard, and that a fourteenth century figure of a civilian is exposed in like manner at Berrow.

The remains of stained glass are mostly concentrated in the noble and beautifully situated church at Winscombe, which forms a perfect treasure-house of fifteenth century painted glass. Like many old examples, colour is here but sparingly introduced, and there is one window of three broad lights, each of which is occupied by a full length single figure entirely in white costume. The dexter of these effigies is that of S. Paul, the central one $\mathrm{S}$. Peter, and the sinister another $\mathrm{S}$. Peter in a canon's dress, and bearing what seems to be a holy water sprinkler, but the identity of this figure I am unable to specify. Another window having four lights has $\mathrm{S}$. Anthony in the outer dexter opening, next comes S. Mary in white dress over which is a crimson mantle and hood; the third light has the Crucifixion, of which Dr. Neale has remarked that the arms of our Lord are not extended, a treatment which is required by the necessities of its position, and therefore bears no Calvinistic signification. The cross has the peculiarity of rising from an ornamental panelled base, and not from a rock: the fourth light has S. John the Evangelist, and beneath each figure are small ones of kneeling donors, bidding their beads and bearing labels with invocations of the saints above them. These windows were restored, or rather the glass was reset, in 1850, and either at that date, or since, the whole of the glass filling one window in the north aisle was transferred to one in the south 
aisle-a freak paralleled by one carried out at the church of Winfrith-Newburgh, Dorset, where the old east window is now the west one, and a north window at present helps to light the south side of the nave.

At East Brent there are several fragments of stained glass, which are described as follows in the Gentleman's Magazine of 1838. "In the windows of that church," it says, " are the remains of some excellent painted glass. In one are the subjects of the Salutation, the Nativity and the Wise Men's Offering ; in another the Virgin with her Infant Son; in another the Scourging; and in others the Imprisonment and Decollation of John the Baptist, and figures of S. John the Evangelist, and S. James the Less." There are many fragments of subjects also at Banwell, and at Compton Bishop are the Annunciation and Coronation of the Blessed Virgin, and the Holy Trinity. At Tickenham, our Lord enthroned is in the east window of the south chapel, and His Crucifixion in a south window of it, the green cross being covered with an ornamental pattern. Christon has a perfect little figure of S. John the Evangelist, with his eagle standing on a closed book, and there are quarries and fragments at Weston-in-Gordano, whilst armorial glass remains at Cheddar and Chelvey.

There is a singular absence of any remains of wall painting in these north-east Somerset churches, and in this respect they compare unfarourably with the churches in Sussex, which, small and unadorned as many of them are, have nearly all exhibited traces of mural decoration in colours. The valuable South Kensington List of Buildings having Mural Decorations, informs us of a S. George painted on the tower at Cheddar; a female holding a cross at Clapton-in-Gordano, and a S. Christopher at Loxton, all of which have perished. At Uphill, the east wall of the chancel is said to have had figures of thirteenth century date pictured upon it. At Clapton-in-Gordano a consecration cross appears on the tympanum of the Norman doorway, and another inside on the north wall of the chancel, also at Chelvey there seems to be one of these crosses also on the north wall. Whilst on the subject of wall paintings, I cannot help remarking on the destruction of the curious picture formerly on the north 
wall of a chapel in S. Cuthbert's Church, Wells. It represented our Lord as the Salvator Mundi, a full length figure with bare feet and arms, but with a globe in the left hand, whilst the right was upheld in benediction; over this effigy was an angel bearing a shield with the five wounds. I notice this picture both because it was a singularly perfect work of the fifteenth century, and also to record its destruction at the restoration of the church which contained it.

But although wall painting is conspicuous by its absence, there are several examples of colour on church fittings, some of which have already been alluded to. At Portbury there exists a mutilated but very richly painted and gilt niche over the south doorway of the porch, and the stone pulpits at Cheddar and Loxton still glow with colour, though the latter is a restoration, and a text on it in English is evidently modern. The colouring of the fine screen at Long Ashton is said to be a careful reproduction of the old.

The churchyard and village crosses are numerous, though none are remarkable. At Bleadon the cross stands outside the churchyard immediately in front of the tower. Yatton possesses the steps and base of a very large cross, and Wraxall has an excellent example, with pedestals for statuettes at the angles of the shaft. In some cases both churchyard and village cross remain as at Congresbury, Kingston Seymour, and Wick St. Lawrence. 